\title{
The Relationship Between Median Age and Death Cases During the Coronavirus Disease 2019 (COVID-19) Pandemic: The Mediating Role of Current Health Expenditure
}

\author{
Koronavirüs Hastalığı 2019 (COVID-19) Pandemisinde Yaş Ortalaması ve Ölüm \\ Olguları Arasındaki ilişski: Cari Sağlık Harcamalarının Aracılık Rolü (GSYïH’nin \\ Yüzdesi)
}

(D) Kerem TOKER, iD Zekiye İrem GÖZÜBOI

Bezmialem Vakif University Faculty of Health Sciences, Department of Health Management, İstanbul, Turkey

\begin{abstract}
Objective: This study aimed to identify and define the relationships among the median ages of countries, their death cases, and current health expenditures [percentage (\%) of gross domestic product (GDP)] during the Coronavirus disease 2019 (COVID-19) pandemic.

Methods: We analyzed the mediating role of current health expenditures (\% of GDP) in the relationship between median age and death cases. Data from 60 countries with the highest COVID-19 cases were analyzed. Correlation and hierarchical regression tests were used in the analyses.

Results: The effect of the median ages of countries on COVID-19 death cases was $27.5 \%$, and on current health expenditures was $56.3 \%$. When the effect of the median age and current health expenditure variables on death cases was analyzed together, the effect of the median age was statistically insignificant and the effect of current health expenditures was $35.4 \%$.

Conclusion: It was determined that current health expenditures have a positive mediating effect on the relationship between COVID-19 deaths and the median age of countries. It was determined that health expenditures did not make any strategic contribution to reducing mortality rates. The results provide an original theoretical framework for countries that aim to develop national health care management strategies.
\end{abstract}

Keywords: Coronavirus disease 2019 (COVID-19) pandemic, median age, death cases, current health expenditure (\% of GDP)

\section{ÖZ}

Amaç: Bu çalışma, Coronavirüs hastalığı 2019 (COVİD-19) Pandemisi sırasında ülkelerin yaş ortalaması, ölüm olguları ve mevcut sağlık harcamaları [gayri safi yurt içi hasıla (GSYİH)'nin yüzdesi (\%)] arasındaki ilişkileri belirlemeyi ve tanımlamayı amaçlamaktadır.

Yöntemler: Mevcut sağlık harcamalarının (GSYİH'nin \%’si), ülkelerin yaş ortalaması ve ölüm olguları arasındaki ilişki üzerindeki aracı rolü incelendi. COVID-19 olgularının en yüksek olduğu 60 ülkenin verileri analiz edildi. Analizlerde korelasyon testleri ve hiyerarşik regresyon testleri kullanıldı.

Bulgular: Ülkelerin yaş ortalamasının, COVİD-19 kaynaklı ölüm olguları üzerindeki etkisi $\% 27,5$, cari sağlık harcamaları üzerindeki etkisi ise \%56,3 bulundu. Yaş ortalaması ve cari sağlık harcaması değişkenlerinin, ölüm olguları üzerindeki etkisi birlikte analiz edildiğinde, yaş ortalamasının etkisi istatistiksel olarak anlamsız, cari sağlık harcamalarının etkisi ise $\% 35,4$ olarak saptandı.

Sonuç: COVİD-19 nedenli ölümlerle ülke yaş ortalamaları arasındaki ilişkide cari sağlık harcamalarının pozitif aracılık rolü olduğu saptandı. Yapılan sağlık harcamalarının ölüm oranlarını azaltmada stratejik bir katkı sağlamadığı tespit edildi. Sonuçlar, ulusal sağlık yönetimi stratejileri geliştirmeyi amaçlayan ülkeler için özgün bir teorik çerçeve sunmaktadır.

Anahtar Sözcükler: Coronavirüs hastalığı 2019 (COVID-19) pandemisi, yaş ortalaması, ölüm olguları, cari sağlık harcamaları (GSYİH'nin \%’si)

Address for Correspondence: Kerem TOKER, Bezmialem Vakif University Faculty of Health Sciences, Department of Health Management, i̇stanbul, Turkey

E-mail: ktoker@bezmialem.edu.tr ORCID ID: orcid.org/0000-000-1904-1406

Received: 11.06 .2020

Cite this article as: Toker K, Gözübol Zi. The Relationship Between Median Age and Death Cases During the Coronavirus Disease 2019 (COVID-19) Pandemic: The Mediating Role of Current Health Expenditure (Percentage of GDP). Bezmialem Science 2020;8(Supplement 2):1-6. 


\section{Introduction}

The coronavirus disease 2019 (COVID-19), which emerged as unexplained pneumonia cases in Wuhan, China in December 2019, is caused by a new coronavirus named Severe Acute Respiratory Syndrome Coronavirus-2 (SARS-CoV-2) by the World Health Organization (WHO) on January 12, 2020 (1). The first 54 COVID-19 cases reported in Wuhan spread across the world, affecting hundreds of thousands of people in 195 countries (2). On March 11, 2020, the WHO declared COVID-19 as a global pandemic after the virus crossed Chinese borders and spread rapidly all over the world. Infection occurs through close contact with an infected person producing respiratory droplets in the range of approximately 1.5 meters during coughing or sneezing (3).

According to the WHO, COVID-19 mortality depends on a person's immunity. Most people infected with SARS-CoV-2 experienced mild to moderate respiratory disease and recovered without special treatment (4). Diseases such as hypertension, diabetes, coronary heart disease, hepatitis $\mathrm{B}$, and cerebrovascular disease are among the main comorbidities that make the course of COVID-19 difficult; they increase the severity of the disease necessitating the use of mechanical ventilators and increase the length of stay in the intensive care unit (2). According to a report published by the WHO, SARS-CoV-2 is transmitted to people of all ages, but the risk of death is higher in the elderly (4). This situation leads to higher mortality rates in countries with an older population. For example, the mortality rate due to the COVID-19 was $2.3 \%$ in China, while the overall mortality was significantly higher (7.2\%) in Italy. When the data were classified by age group, mortality in Italy and China appeared very similar for the 0-69 age group, but mortality rates were higher in Italy for people aged 70 years and above, and especially for those aged 80 years. In addition, mortality at the age of 90 years and above was $22.7 \%$ in Italy.

While there is a close relationship between mortality rates and average age, can health spending have a mediating role in this relationship? Could countries with older populations have reduced mortality rates by allocating more of the state budget for health? Based on these questions, this research aimed to determine the relationship between aging and COVID-19 related deaths and the mediating effect of the current health expenditures [percentage of gross domestic product (GDP)].

\section{Aging and Mortality}

According to the United Nations, people aged 60 years and over are defined as the elderly. However, this is stated as 65 years and over in many conditions (5). The WHO estimates the proportion of the world population over 60 to increase from $12-22 \%$ between 2015 and 2050 (6). The aging population will have an impact on the health system of countries. There are many links between aging and health care. The most critical of these is that an aging population causes the expansion of morbidity in the health system. Expanding morbidity means that healthy life increases less with increasing life expectancy; therefore, people live longer in poor health. The compression of morbidity is the opposite. Healthy life increases more than the increase in general life expectancy, and people become hospitalized for less time. The impact of these conditions on health expenditures is crucial (7).

From the COVID-19 cases examined, there is a relationship between the risk of aging and death (8). Approximately $23 \%$ of Italy's population in 2019, which is one of the countries most affected by the pandemic, is 65 years old and above. Since COVID-19 is more lethal in elderly patients, the elderly population rate in Italy explains the higher mortality/case ratio than in other countries (9). It is thought that this high rate is due to the demographic structure of the country. The median age is 46 years in Italy. Similar results were found in Spain, where the median age is 43.9 years. Over 28,000 COVID-19 deaths have been reported in Spain to date (10). These results show that there is a significant relationship between individuals who lost their lives due to the pandemic and their ages.

\section{Current Health Expenditures}

Health expenditure is crucial for health systems to maintain and develop human well-being. Employment of skilled health professionals, the supply of medical equipment, health promotion, and disease prevention cannot occur without the required funding (11). The level of health spending in a country is the most critical measure of its health investments. Therefore, health expenditure is a major input in improving health indicators, such as exercise and diet (12).

Total health expenditure consists of both public and private health expenditures and is critical for establishing effective health policies at national and regional levels because it has a share of the GDP (13). In 2015, the world spent US $\$ 7.3$ trillion, about $10 \%$ of the global GDP, on health. Health expenditure per GDP is the highest, with an average of about $12 \%$, in high-income countries. Health expenditure in low-income countries accounts for an average of $7 \%$ of GDP and 6\% in middle-income countries (11). The highest increase in health expenditure has been in East African countries in the last decade (13). As one of the countries most affected by the pandemic, the National Health System of Italy has faced the risk of collapse. As a \% of the GDP in the country, health expenditures are expected to decrease from $6.6 \%$ in $2018-2020$ and $6.4 \%$ in 2022 (14). Rezapour et al. (15) found that public health expenditures are more effective than private health expenditures and they improve health conditions by generating positive external effects. Therefore, countries need to provide sufficient financial resources to improve their health systems. Additionally, Rana et al. (16) found a positive relationship between public health expenditure and health sector performance in 30 organisation for economic co-operation and development countries.

In the context of these findings, this research determined the relationship between mortality rates and median age and the mediating role of health expenditure in this relationship by using data from 50 countries with the highest number of deaths in the COVID-19 pandemic. 


\section{Method}

It is a known fact that in the pandemic period, death cases are high in countries with a high median age. Factors such as weakening of the immune system, increase in chronic diseases, and the need for quality care services decrease the ability of patients to fight SARS-CoV-2 as they age. Reduced struggle potential causes the number of deaths to increase in the elderly population. Is there any other factor that affects the structure of the relationship between the median age of the population and death cases? This is the main research question. In the context of strategic health management, as the elderly population grows, demand for healthcare services increases, therefore governments need to allocate more resources to healthcare expenditure. Allocating more resources to healthcare expenditure enables more agile and higher-quality healthcare demands to be met. Thus, there should be a significant decrease in the number of deaths. This relational structure among variables constitutes the conceptual framework of the research and is represented in Figure 1.

Figure 1 shows the mediating role of the current health expenditures (\% of GDP) in the relationship between median age and death cases. The $\mathrm{H}_{1}$ hypothesis in this conceptual framework is as follows:

\section{Sample and Data Collection Tools}

While building datasets to test the research model, we worked with the most up-to-date data possible. Accordingly, the research was conducted by analyzing the data obtained from the first 60 countries with the most COVID-19 cases as of April 13, 2020 (17). This is because the top 60 countries are the countries most affected by the pandemic and are working hard to overcome the situation. Data on death cases were taken from the Worldometer statistics website (17), and data on current health expenditure and median age were obtained from the World Bank's database (18).

\section{Results}

First, the direction and power of the relationships in the research model with each other were analyzed. The correlation analysis results for this purpose are shown in Table 1.

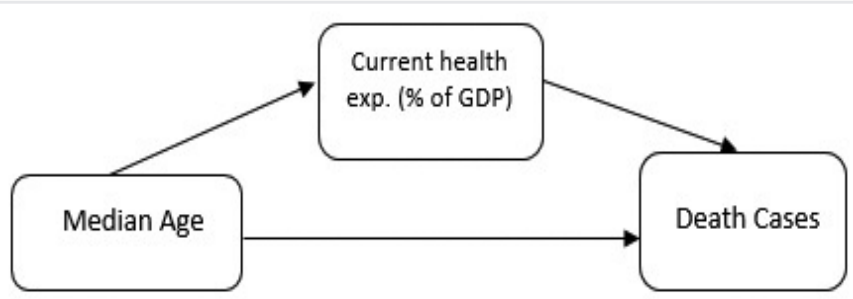

Figure 1. The research model

$\mathrm{H}_{1}$ : In the COVID-19 pandemic, current health expenditures (\% of GDP) have a mediating role in the relationship between death cases in countries and their median age. The next section explains the dataset used to test the $\mathrm{H}_{1}$ hypothesis. \% of GDP: Percentage of the gross domestic product (current health expenditures)
Table 1 shows that there is a positive and significant relationship between the death cases and the median age at the rate of $27.5 \%(r=0.275 ; \mathrm{p}<0.05)$. Schober et al. (19) have stated that a correlation ratio between 0.10 and 0.39 is weak and that between 0.39 and 0.69 is a moderate relationship. According to this result, when the median age of countries increases, the number of deaths also increases, but this relationship is weak. When the relationship between the median age and current health expenditures was examined, a moderate relationship was observed at the rate of $56.3 \%(\mathrm{r}=0.563)$. This showed that there is a higher correlation between median age and current health expenditures than between COVID-19 deaths $(0.275<0.563)$. Finally, when the relationship between health expenditures and the number of deaths was examined, it was found that there was a moderate level of $39.7 \%(\mathrm{r}=0.397)$. Therefore, in the pandemic process, as the current health expenditures of the countries increase, the mortality rates increase moderately. How can this remarkable result be interpreted? Therefore, the effects of the variables on each other should be analyzed.

Hence, the three-stage regression analysis method proposed by Baron and Kenny (20) for the mediating effect test was used. According to the authors, for a variable to have a mediating effect, the effect of the independent variable (median age) on the dependent variable (death cases) is checked. If this effect is statistically significant $(\mathrm{p}<0.05)$, continue to the second stage. In the second stage, the effect of the independent variable on the mediator variable (\% GDP) is tested. If this test result is statistically significant, then move on to the third stage. In the third stage, the effects of both the independent variable (median age) and the mediating variable on the dependent variable (death cases) are analyzed together. In the third test, if the effect of the independent variable is reduced, a partial mediation role is mentioned, and if this effect is eliminated, the full mediation role is mentioned. The regression analysis results performed according to these stages are shown in Table 2.

When Test 1 in Table 2 was analyzed, it was seen that the median age explained $6 \%$ of the changes in deaths due to COVID-19 (Adjusted $\mathrm{R}^{2}=0.060$; F (p) <0.05). This result revealed that, contrary to the general belief in the pandemic situation, there was no high relationship between the death cases and the median age. In Test 1 , the effect of the median age on the death cases was determined to be $27.5 \%$ (Stand. $\beta=0.275 ; \mathrm{p}<0.05$ ). Similarly, this result showed that there was no high effect between the variables. In Test 2 , this time, the effect of the median age on the mediator variable (\% of GDP) was examined. The adjusted $\mathrm{R}^{2}$ was $0.305(\mathrm{~F}(\mathrm{p})<0.01)$. This result demonstrates that the

Table 1. Variables and correlations $(n=60)$

\begin{tabular}{|c|c|c|c|c|}
\hline & Variables & 1 & 2 & 3 \\
\hline 1 & Death cases & 1 & $0.275^{*}$ & $0.397^{* *}$ \\
\hline 2 & Median cases & - & 1 & $0.563^{* *}$ \\
\hline 3 & $\begin{array}{l}\text { Current health } \\
\text { expenditure (\% of GDP) }\end{array}$ & - & - & 1 \\
\hline
\end{tabular}




\begin{tabular}{|c|c|c|c|c|c|c|c|c|}
\hline Test 1 & $\mathrm{R}$ & $\mathrm{R}^{2}$ & Adjusted $\mathrm{R}^{2}$ & $\mathrm{~F}$ & F Sig. & Stand. $\beta$ & $\mathrm{t}$ & $\mathrm{p}$ \\
\hline \multicolumn{9}{|l|}{ Dependent variable: death cases } \\
\hline Independent variable: median age & 0.563 & 0.317 & 0.305 & 26.496 & 0.000 & 0.563 & 5.147 & 0.000 \\
\hline \multicolumn{9}{|c|}{ Dependent variable: current health expenditure (\% of GDP) } \\
\hline $\begin{array}{l}\text { Current health expenditure (\% of } \\
\text { GDP) }\end{array}$ & - & - & - & - & - & 0.354 & 2.388 & 0.020 \\
\hline
\end{tabular}

median age of the countries explained $30.5 \%$ of the change in the resources allocated to current health expenditures. Stand. $B$ was $0.563(p<0.01)$. Accordingly, it can be said that the median age of the population plays a major role in determining the resources to be allocated to the current health expenditures of the countries. As the median age of countries increases, resources allocated from the government budget to health expenditures also increase. Finally, in Test 3, the combined effect of the median age and current health expenditures (\% of GDP) on the death cases was analyzed. Although the regression model established in this test was significant $(F(p)<0.01)$, the effect of the median age was insignificant $(p>0.05)$. The effect of current health expenditures on death cases was determined to be $35.4 \%$ (Stand. $\beta=0.354 ; \mathrm{p}<0.05$ ). According to these results, current health expenditures have a mediating role in the relationship between death cases in countries and their median age. The $\mathrm{H}_{1}$ hypothesis was confirmed.

\section{Discussion}

The COVID-19 pandemic prompted countries to investigate the adequacy of their health systems. While countries such as Germany, Singapore, and South Korea struggled with rapid and effective strategies against the pandemic, countries such as the United States of America, Italy, Spain, and the United Kingdom, responded to the outbreak. This inadequacy caused death rates to increase dramatically. While it was stated that deaths due to high age increased at the beginning of the pandemic, studies conducted later in the pandemic indicated that social norms, social inequalities, and social and cultural context elements such as culture were among the factors affecting the spread of the virus (21). However, no significant relationship was found between the confirmed (positive) cases and death cases. This situation suggests that the quality and capacity of health systems may have an impact on death cases. Are the quality and capacity of the health systems of the countries related to the health expenditures that the countries allocate from GDP? This is because governments disburse these healthcare expenditures to establish a better healthcare system.

The hypothesis of this research was developed within the framework of these questions. First, the relationship between the median age of countries and deaths from COVID-19 was examined. For this purpose, the data of the first 60 countries with the highest number of death cases were included in the analysis. The results revealed a positive and significant $(\mathrm{p}<0.05)$ relationship between the median age of countries and the death cases at $27.5 \%$. However, this was still a weak relationship. Could there be another variable that determines the direction and strength of the relationship between these variables? The ratio of the health expenditures of countries to their GDP is a critical indicator of their need for health services. When the relationship between death cases and health expenditure rates was analyzed, it proved that approaching the issue from this context was accurate. The relationship between the two variables was $39.7 \%$, which was significant $(p<0.01)$. This result has demonstrated that the strength of the relationship between the current health expenditures and the death cases is higher and significant compared to the median age.

Following these findings, a mediating test was performed to determine the structure of the relationship between the variables. For this purpose, the three-stage regression analysis method proposed by Baron and Kenny (20) for mediating testing was used. According to the results, although the regression model established in the third test was significant $(F(p)<0.01)$, the 
effect of the median age was found to be insignificant $(\mathrm{p}>0.05)$. The effect of health expenditures on death cases was determined to be $35.4 \%$ (Stand. $ß=0.354 ; \mathrm{p}<0.05$ ). According to this result, the current health expenditures (\% of GDP) have a mediating role in the relationship between COVID-19 death cases and median ages. The $\mathrm{H}_{1}$ hypothesis was therefore confirmed.

\section{Conclusion}

This result revealed that countries with high median ages make more healthcare expenditures, but these expenditures are insufficient in reducing the impact of large and unexpected crises such as pandemics. However, strategic health management aims to address these risks predictable by writing scenarios for enormous risks. It was determined that the countries that made high expenditures to improve their health sectors could not reduce the number of deaths and that only monetary expenditure was insufficient. It can be stated that the ability to manage and organize the health system is necessary to generate positive results. In this context, there is a need for intangible resources such as strategic management skills as well as tangible resources such as finance.

However, there are several limitations of the research. The first limitation is that data were collected from 60 countries. As more countries will be included in the pandemic in the next time, the model can be retested with more countries. Second, different independent variables such as chronic/hereditary diseases can be included in the research model. However, it is difficult to obtain high-reliability data on these issues. This type of model test can only be done on local basis, not globally. Third, the research was conducted with data from a single time section. Therefore, the results obtained can be just interpreted for this time section. The longitudinal research method can be applied to re-analyze the model by periodically collecting data. Thus, stronger statistical evidence can be obtained by controlling the internal consistency of the model.

\section{Ethics}

Ethics Committee Approval: Data on death cases were taken from the Worldometer statistics website, and data on current health expenditure and median age were obtained from the World Bank's database.

Peer-review: Externally and internally peer reviewed.

\section{Authorship Contributions}

Concept: K.T., Design: K.T., Data Collection or Processing: Z.I.G., Analysis or Interpretation: K.T., Literature Search: Z.İ.G., Writing: K.T., Z.İ.G.

Conflict of Interest: No conflict of interest was declared by the authors.

Financial Disclosure: The authors declared that this study received no financial support.

\section{References}

1. Sun P, Xiaosheng L, Chao X, Wenjuan S, Bo P. Understanding of COVID-19 based on current evidence. J Med Virol 2020;92:548-51.

2. Saxena SK. (ed.). Coronavirus Disease 2019 (COVID - 19). Epidemiology, Pathogenesis, Diagnosis, and Therapeutics. Singapore:Springer;2020.

3. Ghinai I, McPherson TD, Hunter JC, Kirking HL, Christiansen D, Joshi K, et al. First known person-to-person transmission of severe acute respiratory syndrome coronavirus 2 (SARS-CoV-2) in the USA. Lancet 2020;395:1137-44.

4. World Health Organization. Report of the WHO-China joint mission on Coronavirus Disease 2019 (COVID-19). Last Accessed Date: 12.04.2020 Avaialable from: https://www.who.int/docs/ default-source/coronaviruse/who-china-joint-mission-on-covid-19final-report.pdf.

5. The United Nations. New measures of population ageing. Last Accessed Date: 12.04.2020 Available from: https:/www.un.org/ en/development/desa/population/events/pdf/expert/29/session1/ EGM_25Feb2019_S1_SergeiScherbov.pdf

6. World Health Organization. Aging and health. Last Accessed Date: 14.04.2020. Available from: https://www.who.int/news-room/factsheets/detail/ageing-and-health Retrieved date:

7. Berlatsky N. Aging. 1st edition. Michigan:Greenhaven Publishing;2014.

8. Wu Z, McGoogan JM. Characteristics of and Important Lessons From the Coronavirus Disease 2019 (COVID-19) Outbreak in China: Summary of a Report of 72314 Cases From the Chinese Center for Disease Control and Prevention. JAMA 2020;323:1239-42.

9. Onder G, Rezza G, Brusaferro S. Case-fatality rate and characteristics of patients dying in relation to COVID-19 in Italy. JAMA 2020;323:1775-6.

10. Sannigrahi S, Pilla F, Basu B, Basu AS. The overall mortality caused by COVID-19 in the European region is highly associated with demographic composition: A spatial regression-based approach. arXiv preprint arXiv:2005.04029. 2020:1-43.

11. World Health Organization. Public spending on health: A closer look at global trends Last Accessed Date: 13.04.2020. Avaialable from: https://www.who.int/health_financing/documents/healthexpenditure-report-2018/en/

12. Kiross GT, Chojenta C, Barker D, Loxton D. The effects of health expenditure on infant mortality in sub-Saharan Africa: evidence from panel data analysis. Health Econ Rev 2020;10:1-9.

13. Bein MA, Unlucan D, Olowu G, Kalifa W. Healthcare spending, and health outcomes: evidence from selected East African countries. Afr Health Sci 2017;17:247-54.

14. Armocida B, Formenti B, Ussai S, Palestra F, Missoni E. The Italian health system and the COVID-19 challenge. Lancet Public Health 2020;5:e253.

15. Rezapour A, Mousavi A, Lotfi F, Movahed MS. Alipour S. The effects of health expenditure on health outcomes based on the classification of public health expenditure: A panel data approach. Shiraz E-Med J 2019;20:1-7. 
16. Rana RH, Alam K, Gow J. Development of a richer measure of health outcomes incorporating the impacts of income inequality, ethnic diversity, and ICT development on health. Globalization Health 2018;14:1-12.

17. Worldometer. reported cases and deaths by country, territory, or conveyance. Last Accessed Date: 13.04.2020. Available from: https://www.worldometers.info/coronavirus/ ?utm_ campaign=homeAdvegas 1 ?

18. The World Bank. World development indicators. 2020. Last Accessed Date: 13.04.2020. Available from: https://databank.worldbank.org/ home
19. Schober P, Boer C, Schwarte LA. Correlation Coefficients: Appropriate Use and Interpretation. Anesth Analg 2018;126:176368.

20. Baron RM, Kenny DA. The moderator-mediator variable distinction in social psychological research: conceptual, strategic, and statistical considerations. J Pers Soc Psychol 1986;51:1173-82.

21. Bave JJV ,Baicker K, Boggio PS, Capraro V, Cichocka A, Cikara M, et al. Using social and behavioural science to support COVID-19 pandemic response. Nat Hum Behav 2020;4:460-71. 